\title{
Development of a Uniform Approach to Writing and Grading of Laboratory Reports in Horticultural Science Courses
}

\author{
Neil O. Anderson ${ }^{1, *}$, Emily Hoover ${ }^{1}$, Bernadette Longo ${ }^{2}$ \& Marjorie Ross $^{3}$ \\ ${ }^{1}$ Department of Horticultural Science, 1970 Folwell Avenue, University of Minnesota, USA \\ ${ }^{2}$ Department of Writing Studies, Institute for Advanced Study, University of Minnesota, USA \\ ${ }^{3}$ Department of Horticultural Science, University of Minnesota, USA \\ *Correspondence: Department of Horticultural Science, 1970 Folwell Avenue, University of Minnesota, USA. \\ E-mail: ander044@umn.edu
}

Received: January 28, 2018

Accepted: February 25, 2018 Online Published: April 2, 2018

doi:10.5430/jct.v7n1p125

URL: https://doi.org/10.5430/jct.v7n1p125

\begin{abstract}
Written scientific communication, such as laboratory reports, are important components of undergraduate education within the sciences. Since most Horticultural Science majors offer lecture- and lab-based courses, students often write laboratory reports for many courses across the curriculum and these reports comprise a large percentage of the writing assignments in these classes. Instructors link learning objectives with laboratory reports to reinforce course content. Students have noted inconsistencies across horticulture courses in requirements for laboratory report writing, which often leads to confusion. Thus, development of a grading rubric would improve the continuity of expectations of laboratory report writing and grading within a Horticultural Science curriculum for instructors teaching courses requiring laboratory reports.

When focusing just on laboratory writing in the curriculum, surveys and interviews indicated that a disconnect exists between what instructors expect of their students and what the stated learning outcomes were for their courses. Student's ability to analyze results was seen as both a strength and weakness, as reported from faculty responses. In lower division courses, analyzing results from student's experiments was a weakness while in upper division courses faculty responses were mixed as to whether students had the skills to sufficiently analyze results from their experiments.

When a grading rubric was trialed, students indicated that use of the same rubric in other Horticultural Science courses would demystify the process of conducting research and communicating it effectively in laboratory reports. For this work to expand, one or more standard rubrics need to be developed for use by Horticultural Science courses within an institution to enhance our students' abilities to become competent writers in this form of scientific communication. A baseline rubric for courses at the 3000 level was developed to serve as a template to further this process.
\end{abstract}

Keywords: science education, rubrics, written communication

\section{Introduction}

The development, implementation, and use of writing across curriculum (McLeod, 1992) is essential for science-based disciplines, such as horticulture (Holford, Ellis \& Haigh, 2001). While Bachelor of Science graduates are expected to communicate at a professional level, both orally and in writing, the methodology to achieve this goal varies by institution. For instance, The University of Western Sydney, Australia, has implemented a writing portfolio to enhance skill building in writing in the discipline (Holford, Ellis \& Haigh, 2001). Other programs use the more traditional assignment-based approach to evaluating student learning throughout their major coursework. Since most horticultural science courses are lecture- and lab-based, students often write laboratory reports for many courses across the curriculum, and these reports comprise a large percentage of the writing assignments in these courses.

\subsection{The Importance of Laboratory Report Writing: An Overview}

Why do we have students write laboratory reports? What do we hope students learn in the process? Goals for 
laboratory report writing can include resolving misconceptions students have about the science they are learning, developing skills in logical thinking and organization, or understanding the nature of science (Lazarowitz \& Tamir, 1994). We also use writing in the sciences as a method of teaching scientific inquiry. The National Academy of Sciences encourages writing as the best method for teaching the skills of scientific inquiry including question formulation, experimental design, methodology, critical thinking and analysis and communication of scientific information (National Research Council, 1996). To meet these learning objectives, a writing portfolio may be required for graduating students as a visible indication they have mastered the scientific process (Holford, Ellis \& Haigh, 2001). Additionally, Campbell, Loveness, Saalih, Buffler \& Lubben (2000) and Rudd, Greenbowe \& Hand (2002) suggest that instruction of laboratory report writing should go beyond basic structural components to include investigative procedures and data handling.

\subsection{Development and Implementation of Rubrics}

An important issue raised by college and university science teachers attempting to integrate writing into courses is the work load in reading and critiquing many lengthy writing assignments (Brillhart \& Debs, 1981), especially in large introductory-level courses. Brillhart \& Debs (1981) recommend that instructors use a consistent format for laboratory reports throughout the semester and maintain that format to develop students' expectations for each section of the laboratory report. This structure allows instructors to focus attention on individual laboratory report sections at different stages in the course and spend less time on those that have been mastered. To further simplify the task of grading, Whelan \& Zare (2003) suggest development of a rubric that closely mirrors the expectations list provided to students. A rubric is defined as a coherent scoring instrument that delineates specific criteria and performance metrics for learning instead of "tasks" in an assignment (Brookhart, 2013; Dorman, Alpi \& Chappell, 2013). Analytic scoring rubrics are matrices with specific descriptions of expectations for students in order to receive a specific score or grade for all or part of an assignment (Ramey, VandeVusse \& Gosline, 2007; Connors, 2008). This allows instructors and teaching assistants to quickly evaluate students' skills in the desired areas and show students specific areas in need of improvement without the instructor having to write lengthy comments.

Rubrics, defined as survey instruments in matrices with specific delineation of each expectation for a multi-stepped exercise for unbiased evaluative purposes (Ramey, VandeVusse \& Gosline, 2007; Clark \& Libarkin, 2011; Moss \& Brookhart, 2012), are useful for instructors as well as students. Relevant factors and components are critical for a functional and effective rubric to measure student skills, while superfluous and inconsequential factors, e.g. grammatical errors, are excluded (Connor, 2008). Testing of an analytical scoring rubric demonstrated their value as student evaluative tools for mastering writing assignments and providing grading consistency by instructors for both K-12 and university students (Moskal \& Leydens, 2007; Andrade, Du \& Mycek, 2010; Connor, 2008; Alles \& Riggs, 2011; Moss \& Brookhart, 2012; Brookhart, 2013).

Chandler, Fridley, Weber \& Keith (2005) developed a 5-point rubric as a tool for evaluating the effectiveness of teaching a laboratory. Their rubric was designed with "an optimal format for each criteria" (Chandler, Fridley, Weber \& Keith, 2005, p.15). Barringer (2008) posited that development of a grading rubric saves instructors considerable amounts of time by minimizing the writing of comments on student papers and clarifying for students the expectations for assignments prior to initiating the writing process. The long-term benefit is enhanced student learning. Writing laboratory reports can help students integrate the conceptual theories of science with the practical. Others have noted the benefits of using laboratory reports to teach course content while emphasizing the important role of writing in science (Brillhart \& Debs, 1981; Whelan \& Zare, 2003). The Center for Writing at our institution offers web-based resources for students to use when writing in the sciences. However, these instructions need to be customized to help students in particular curricula.

\subsection{The Need for Consistency Across Grading Rubrics in a Curriculum}

While several disciplines and curricula within institutions have successfully developed and implemented rubrics for assessment of student writing (Andrade, Du \& Mycek, 2010), many have not engaged in the process to date. Environmental Horticulture undergraduate students enroll in 1000, 3000, 4000, and 5000 level coursework (with a "HORT" designator) in the Department of Horticultural Science at the University of Minnesota, choosing one of five programs: Landscape Design, Landscape Implementation and Management; Floriculture/Nursery Production and Retail Management; Turfgrass Science or Individualized Program of Study. Several departmental faculty have been instrumental in enhancing Environmental Horticulture courses with implementation of critical thinking/free-writing exercises or "reflective learning" (Foulk \& Hoover, 1996), cooperative learning (Anderson, 2000), development of decision cases (Davis, 1992a, 1992b; Foulk \& Hoover, 1997; Hoover, 1993; Meyer \& Allen, 1994) and case studies (Anderson, 2001a, b; 2002), online learning (Anderson \& Walker, 2003), writing across the curriculum (Zambreno, 
Hoover, Anderson \& Gillman, 2004), and writing-intensive curricular enhancement (Anderson, 2003). This has led individuals within our department to take on national leadership in teaching pedagogy and active learning within the discipline.

A common student complaint in laboratory-based courses across the Environmental Horticulture curriculum is the lack of consistency or a unifying approach to writing laboratory reports. As students progress through the Environmental Horticulture curriculum, they experience differing writing requirements in each course (contents, statistical analyses and interpretation, intended audience, writing style) and/or discipline, rather than building on writing practices from previous classes. The Environmental Horticulture curriculum would benefit from the development of one or more "best practices" guidelines, such as rubrics (Gibson \& Liebman, 2003; Johnson, Johnson \& Smith, 1998), for writing and grading laboratory reports in the discipline.

\subsection{Research Objectives}

We first identified classes in which written communication skills, specifically laboratory report writing, are taught with the HORT designator within the Environmental Horticulture curriculum. The primary objective was to develop a grading rubric to be made available to instructors teaching courses requiring laboratory reports to improve the continuity of expectations of laboratory report writing and grading within the curriculum. We assume that development and implementation of a rubric will lead to success in teaching scientific writing as well as providing meaningful learning for students across courses within the curriculum. The rubric was then tested in a secondary objective using three sample courses (with laboratory report requirements), taught by the same instructor, for its effectiveness in grading and promoting student comprehension in: Hort 3002W (Greenhouse Management), Hort 4141W (Plant Production II), and Hort 5051 (Plant Production I).

\section{Method}

To fulfill our objectives we began by collecting syllabi for each course, which meets for lectures and/or laboratories in the Environmental Horticulture curriculum, taught within the Department of Horticultural Science (Zambreno, Hoover, Anderson \& Gillman, 2004). Courses, such as HORT 4096 (Professional Experience Program) or HORT 5090 (Directed Studies), which are not lecture-based were excluded from the study.

\subsection{In-person Surveys}

In-person surveys were conducted with instructor(s) for each course for a total of $n=15$ survey interviews (Table 1). Each instructor was asked a series of four questions with associated response categories (Table 1). In the cases where there were multiple sections of a course, all instructors were interviewed separately. The survey questions related to each course's learning objectives, how the laboratory report writing related to these objectives, and the strongest/weakest aspects of student performance with the laboratory reports (Table 1).

Responses from instructors to the survey questions were collated for each question and numbered consecutively. If an instructor had multiple responses to a question, each response was assigned its own number. These numbered responses were used to develop a categorization scheme for each question (Geisler, 2004).

\subsection{Independent Review}

A panel of three independent reviewers individually placed each response into only one of the initial categories. Then agreement among the reviewers was evaluated. Categories then were refined to improve agreement to $70 \%$ or greater for these three reviewers (Table 2; Geisler, 2004). A panel of three additional external, independent reviewers categorized the responses according to the refined categories for a final total of six reviewers rating each response from each instructor.

Categorizations from the six total reviewers were combined. If a response received at least three out of six evaluators placing it into a specific category, then the response was included in that category. In cases where $<50 \%$ of the reviewers agreed upon the categorization, the response was not used. A total of $2 / 38$ responses received $\leq 50 \%$ reviewer agreement on categorization for Question 1 (Table 1), 1/42 for Question 2, 3/35 for Question 3, and 2/37 for Question 4, respectively. The number of responses within each category for each question was totaled and converted to percent. Categories for each question are reported for all courses and then broken down into freshman/sophomore courses (1000-3000 level) and junior/senior courses (4000-5000 level).

\subsection{Rubric Development}

The departmental teaching instructors ( $\mathrm{n}=13$ registered) also participated in a teaching retreat on $13 \mathrm{Jan}$. 2005, to discuss the initial survey results and curricular goals for writing within courses. The need to develop a rubric for 
laboratory reports was identified for unifying writing expectations within the curricular foundation courses with laboratory reports. Well-developed rubrics eliminate including irrelevant factors, e.g. grammatical errors or sentence construction, thus providing a coherent and dependable guide for student performance (Moskal \& Leydens, 2007). This need mirrored the findings of Haug (1996) that educating students to write effectively needs to be addressed by instructors across a curriculum with unified goals. Grading rubrics, along with a listing of technical criteria for experimentation, have been tested within agriculture-based courses for writing scientific paper assignments (Aaron, 1996; Gibson \& Liebman, 2003; William, Davis, Cramer, Stephens, Gresswell, Stephenson \& Corcoran, 1999) or for writing portfolios (Holford, Ellis \& Haigh, 2001). In some courses, active-learning activities have also been developed for writing scientific papers using the "read and explain pairs" active-learning technique (Johnson, Johnson \& Smith, 1998) or peer reviews (Gibson \& Liebman, 2003). These studies show that grading rubrics significantly improve students' performance in the writing of scientific papers.

Table 1. Survey Questions with Response Categories Listed Underneath Questions Asked of Instructors Teaching Courses with Laboratories in the Environmental Horticulture Curriculum at the University of Minnesota

\section{What are the learning objectives related to lab reports for this course?}

- Mechanics (writing): Grammar, spelling, style, usage, punctuation, typographic errors, proofreading and editing, writing quality

- Research skills: Keeping data organized; summarizing, analyzing, and presenting data/results; good data collection practices; experimental design; scientific method; library research

- Career: Understanding professional practices; thinking about career positions related to the course

- Course content/synthesis: Plant identification; method or procedure use and recognition; understand and use vocabulary related to course topics; use of conceptual information learned in lecture; make connections between lecture/lab materials; go beyond data to draw conclusions; apply concepts to "real world" problems

- Effective communication: Formally presenting scientific information (objectives, methods, results, discussion, conclusion); accommodating material to a variety of audiences

2. How do the lab report assignments relate to course learning objectives?

- Communicate research: Emphasis on communicating procedures, results, analysis and conclusions; accommodating material to a variety of audiences

- Learn scientific methods: Emphasis on learning basic method(s) of scientific inquiry and information gathering

- Apply scientific methods: Emphasis on statistically analyzing, interpreting data, drawing conclusions; discussing data in relation to initial expectations; possibly using outside sources

- Synthesis: Make connections between lecture/lab materials; apply lecture materials to laboratory work and vice versa; go beyond data to draw conclusions; apply concepts to "real world" problems

3. What is the strongest aspect of student performance on lab reports?

- Laboratory records and reports: Keeping data organized; summarizing and presenting data/results; good data collection practices

- Analyzing results: Analyze and interpret data; draw conclusions; discussing data in relation to initial expectations; possibly tie to outside sources

- Mechanics (writing): Grammar, spelling, style, usage, punctuation, typographic errors, proofreading and editing, writing quality

- Synthesis: Make connections between lecture/lab materials; go beyond data to draw conclusions; apply concepts to "real world" problems

4. What is the weakest aspect of student performance on lab reports?

- Laboratory records and reports: Keeping data organized; summarizing and presenting data/results; good data collection practices

- Analyzing results: Analyze and interpret data; draw conclusions; discussing data in relation to initial expectations; possibly tie to outside sources

- Mechanics (writing): Grammar, spelling, style, usage, punctuation, typographic errors, proofreading and editing, writing quality

- Synthesis: Make connections between lecture/lab materials; go beyond data to draw conclusions; apply concepts to "real world" problems 


\section{Findings}

\subsection{Independent Review Findings}

One of the most important findings linking learning objectives with laboratory reports in the courses taught in horticultural science was instructors' desire to reinforce course content through these assignments (Table 2, Question 1). This relationship between learning objectives and laboratory reports is particularly important at the higher-level courses. Across the curriculum, course content/synthesis (56\%), research skills (25\%), effective communication (16\%), and career (3\%) were categorized as important learning objectives related to laboratory reports, when pooled for all courses (Table 2, Question 1).

Interestingly, teaching the mechanics of writing a laboratory report does not appear in any of the learning objectives for any of the courses ( $0 \%$, Table 2, Question 1) but $21 \%$ of the responses overall indicated that mechanics were a weakness in student writing (Table 2, Question 4). Mechanics were the weakest aspect of student performance on laboratory reports with upper division courses (12\%; Table 2, Question 4). Clearly, the development of mechanic skills was viewed as essential in higher division courses. However, students had little or no demonstrable means of developing such skills when lower division foundation courses did not include mechanics as a learning objective. It is unknown whether students with the desirable mechanic skills obtained these skills from lower division foundation coursework or from independent courses (e.g. HORT 4096 or HORT 5090), which were excluded from this study. This finding is not peculiar to horticulture students. For instance, students in weed biology and ecology at Iowa State University benefited from the incorporation of active-learning techniques to understand the mechanics of writing laboratory reports prior to completing the required assignment (Gibson and Liebman, 2003). The lack of instruction on mechanics in the Environmental Horticulture curriculum is an important void to be resolved.

In lower division courses, the development of research skills (Table 2, Question 1) appeared in over half (56\%) of the responses about learning objectives. As the students advanced to upper division courses, this skill was assumed to have been mastered and was not emphasized (13\%; Table 2, Question 1). However, such skills were not adequately mastered in either lower or upper division courses since both had tasks such as analyzing results ranked as the weakest aspect (50\%) of student performance on laboratory reports (Table 2, Question 4), although significant improvement was noted from lower division (23\%) to upper division (50\%) courses for ranking "analyzing results" as one of the strongest aspects (Table 2, Question 3). It is not known whether inadequate mastering of such skills is due to the lack of educating students in research skills and/or students' value perception of such skills. Gibson and Liebman (2003) reported that students' perception of a laboratory experiment as a valuable activity was poorly and not significantly correlated $(r=0.39, P=0.11)$ with students' ability to analyze simple research data.

As suspected, course content and synthesis are important attributes for including laboratory reports in courses with over half of the responses for all classes (56\%) in this category (Table 2, Question 1). Course content and synthesis were stated as learning objectives more often for the upper division (70\%) versus the lower division (22\%) courses (Table 2, Question 1). For all courses, synthesis (30\%) was equally related to the course learning objectives with respect to "apply scientific methods" (30\%) and "communicate research" (30\%) (Table 2, Question 2). Despite this, however, for all courses synthesis was the lowest ranked (13\%) strength (Table 2, Question 3) and the second weakest aspect (25\%; Table 2, Question 4) for instructor perceptions of student performance on laboratory reports. This is in contrast to previous studies wherein student performance when engaged in cooperative learning exercises to learn the scientific method was highly and significantly correlated $(r=0.73, P \leq 0.001)$ with improving their critical thinking skills (Gibson and Liebman, 2003).

When the question was asked about laboratory reports relating to course objectives, there was an even distribution of responses across categories (30\%) except for teaching the scientific method (10\%) (Table 2, question 2). Communicating research, applying the scientific method, and synthesizing course material were all given equal weight when all courses were analyzed. Even when separated by course designator, the differences among these categories were small.

In specifically asking about the strengths of student laboratory report writing, responses indicated that keeping laboratory records (35\%) and analyzing results (35\%) were strengths, with mechanics (17\%) and synthesizing results (13\%) into the greater body of scientific literature being substantially less (Table 2, Question 3). Contrasting the strengths with the weaknesses, analysis of results was seen as both a strength and a weakness (35\% and $50 \%$, respectively; Table 2, Questions 3 and 4). In lower division courses it was a greater weakness while in upper division courses, some instructors were pleased with their student's abilities while others felt analysis of data should be strengthened. 
Table 2. Categorization of Responses from Survey in Answer to the Survey Questions 1-4. All courses refer to all courses taught within the Department of Horticultural Science that were in the survey. Note: the 1000 to 3000 level courses are freshman/sophomore courses; 4000 to 5000 level courses are junior/senior courses

\begin{tabular}{|c|c|c|c|}
\hline & (\%) & & \\
\hline Category & $\underline{\text { All courses }}$ & $\underline{1000-3000 \text { level }}$ & 4000-5000 level \\
\hline \multicolumn{4}{|c|}{ 1. What are the learning objectives related to lab reports for this course? } \\
\hline Mechanics & 0 & 0 & 0 \\
\hline Research skills & 25 & 56 & 13 \\
\hline Career & 3 & 11 & 0 \\
\hline Course content/synthesis & 56 & 22 & 70 \\
\hline Effective communication & 16 & 11 & 17 \\
\hline \multicolumn{4}{|c|}{ 2. How do the lab report assignments relate to the course learning objectives? } \\
\hline Communicate research & 30 & 35 & 25 \\
\hline Learn scientific methods & 10 & 6 & 15 \\
\hline Apply scientific methods & 30 & 35 & 25 \\
\hline Synthesis & 30 & 24 & 35 \\
\hline \multicolumn{4}{|c|}{ 3. What is the strongest aspect of student performance on lab reports? } \\
\hline Laboratory records and reports & 35 & 38 & 30 \\
\hline Analyzing results & 35 & 23 & 50 \\
\hline Mechanics & 17 & 23 & 10 \\
\hline Synthesis & 13 & 15 & 10 \\
\hline \multicolumn{4}{|c|}{ 4. What is the weakest aspect of student performance on lab reports? } \\
\hline Laboratory records and reports & 4 & 0 & 13 \\
\hline Analyzing results & 50 & 50 & 50 \\
\hline Mechanics & 21 & 25 & 12 \\
\hline Synthesis & 25 & 25 & 25 \\
\hline
\end{tabular}

\subsection{Rubric Development}

As a first step to building skills through the curriculum, we then took the information gathered through the surveys and discussions to develop a grading or analytic scoring rubric for laboratory reports in Environmental Horticulture courses at the 3000 level (Table 3). This exercise allowed us to think about best practices for students writing laboratory reports, to increase the consistency among graders, and to unify goals within the curriculum (Haug, 1996). The grading rubric was the first one developed for use by the department for foundation courses, which require laboratory reports.

The rubric covers all of the technical specifications of a scientifically-written laboratory report using the American Society for Horticultural Science style manual for publications (ASHS, 2002) along with the corresponding assigned grades (A-F scale): title and author(s) of the paper, introduction (including objective and hypothesis), materials and methods, results, discussion, literature cited, and mechanics (Table 3). A sample laboratory report from a previous course section was used to exemplify what an "A" quality paper should contain for technical specifications, primary literature sources, synthesis, and writing quality. Such a rubric emulates those created for other courses in similar disciplines (Aaron, 1996; Gibson and Liebman, 2003; William, Davis, Cramer, Stephens, Gresswell, Stephenson \& Corcoran, 1999) that are reliable to assess student writing and critical thinking as well as providing instructors a rapid and consistent method for grading (Connors, 2008). When the rubric was used with an "A" quality paper, students could use both to critique their laboratory writing assignment. These were used for the first time in spring semester, 2005, for HORT 3002W (Greenhouse Management), a writing-intensive foundation course. Students implemented the grading rubric in assessing their writing, prior to submission of their laboratory reports for grading. Both the grading rubric (Table 3) and the sample "A" paper provided clear benchmarks for writing high quality papers. When polled by the instructor, the students indicated that use of the same rubric in other Environmental Horticulture courses would demystify the process of conducting research and communicating it effectively for the discipline. 
Table 3. An Example of a Grading Rubric Developed for Grading Lab Reports for Horticulture Classes at the 3000 (Sophomore/Junior) Level

\begin{tabular}{|c|c|c|c|c|}
\hline & \multicolumn{4}{|l|}{ Grade assigned } \\
\hline & A & B & C & D \\
\hline $\begin{array}{l}\text { Title and author } \\
\text { of paper } \\
\text { (1 point) }\end{array}$ & $\begin{array}{l}\text { Descriptive title encompassing the } \\
\text { paper's objectives and salient } \\
\text { feature(s). Includes all authors in the } \\
\text { order of their contribution to the } \\
\text { paper, including affiliation. Overall } \\
\text { reflection of higher-level thinking and } \\
\text { writing. }\end{array}$ & $\begin{array}{l}\text { Title effectively } \\
\text { communicates research } \\
\text { objective(s), but does not } \\
\text { reflect research findings } \\
\text { and/or authorship fails to } \\
\text { reflect the contributions. }\end{array}$ & $\begin{array}{l}\text { Title lists objective(s) but does } \\
\text { not communicate either the } \\
\text { research objectives or their } \\
\text { meaning. Authorship lists the } \\
\text { contributors but does not } \\
\text { reflect their contribution. }\end{array}$ & $\begin{array}{l}\text { Fails to communicate through } \\
\text { writing both the intent and } \\
\text { findings of the research, as } \\
\text { well as authorship } \\
\text { contributions and affiliation. }\end{array}$ \\
\hline $\begin{array}{l}\text { Introduction } \\
\text { (Objective and } \\
\text { hypothesis) } \\
\text { ( } 2 \text { points) }\end{array}$ & $\begin{array}{l}\text { Through the use of primary and } \\
\text { secondary literature, the writing } \\
\text { reflects the state of the scientific } \\
\text { understanding and background of the } \\
\text { research topic, relating it to the next } \\
\text { logical research to be conducted. The } \\
\text { introduction leads the reader into the } \\
\text { research objectives and hypothesis } \\
\text { being tested. High quality writing } \\
\text { reflects the authors' insight and } \\
\text { contains one or more higher level } \\
\text { thinking goals of professional writing. } \\
\text { Research objectives reflect the } \\
\text { generative nature of the project. }\end{array}$ & $\begin{array}{l}\text { Sets the background, } \\
\text { scientific stage with primary } \\
\text { and secondary literature } \\
\text { leading into the objective } \\
\text { and hypothesis, but does not } \\
\text { connect them. High quality } \\
\text { writing is used, but does not } \\
\text { reflect higher level thinking } \\
\text { when presenting the } \\
\text { objective and hypothesis of } \\
\text { the experiment }\end{array}$ & $\begin{array}{l}\text { The primary and secondary } \\
\text { literature is briefly reviewed as } \\
\text { statements; objectives and } \\
\text { hypothesis are listed. Authors } \\
\text { fail to elaborate on the factual } \\
\text { background information, relate } \\
\text { it to the current experiment, or } \\
\text { express any higher-level order } \\
\text { of thinking. }\end{array}$ & $\begin{array}{l}\text { Writing fails to cover the } \\
\text { body of literature in a } \\
\text { cohesive fashion; objectives } \\
\text { and hypothesis are unclear or } \\
\text { missing, and no higher-level } \\
\text { thinking is evident. The } \\
\text { primary literature has been } \\
\text { overlooked and all citations } \\
\text { are from the secondary } \\
\text { literature, e.g. popular press } \\
\text { articles, web-based citations, } \\
\text { and/or personal } \\
\text { communication(s). }\end{array}$ \\
\hline $\begin{array}{l}\text { Materials and } \\
\text { Methods } \\
\text { (2 points) }\end{array}$ & $\begin{array}{l}\text { The writing clearly and logically } \\
\text { explains the methodology } \\
\text { implemented to conduct the } \\
\text { experiment and analyze the results } \\
\text { such that anyone anywhere in the } \\
\text { future could completely and } \\
\text { thoroughly replicate the experiment. } \\
\text { The writing reflects the rigor of the } \\
\text { experiment and creates "faith" in the } \\
\text { authors as reliable scientists. The } \\
\text { primary literature is cited as } \\
\text { appropriate. }\end{array}$ & $\begin{array}{l}\text { The techniques and } \\
\text { methodologies used to } \\
\text { conduct the study are not } \\
\text { presented in a logical, } \\
\text { cohesive fashion. Some } \\
\text { techniques may not be } \\
\text { clearly matched with the } \\
\text { objectives and hypothesis, } \\
\text { leaving the reader to figure } \\
\text { out why they were used. The } \\
\text { primary literature is also } \\
\text { cited as needed. }\end{array}$ & $\begin{array}{l}\text { Includes all of the techniques } \\
\text { used but the appropriateness of } \\
\text { one or more is unclear, } \\
\text { confusing the reader. Thus a } \\
\text { reader who desires to } \\
\text { understand the paper or repeat } \\
\text { the experiment would find it } \\
\text { necessary to read the primary } \\
\text { literature citations to } \\
\text { understand how to use these } \\
\text { techniques in question. }\end{array}$ & $\begin{array}{l}\text { Techniques } \\
\text { methodologies are presented } \\
\text { as a list. One or more } \\
\text { methods are not included } \\
\text { and/or the plant material, } \\
\text { growing environment, or } \\
\text { statistical analyses are } \\
\text { missing. Use of the primary } \\
\text { literature may also be } \\
\text { lacking. }\end{array}$ \\
\hline $\begin{array}{l}\text { Results } \\
\text { (8 points) }\end{array}$ & $\begin{array}{l}\text { The research findings are presented in } \\
\text { a coherent, logical fashion with the } \\
\text { appropriate supporting documentation } \\
\text { (tables/figures) and statistics. Data } \\
\text { presentation in tables and figures } \\
\text { enables easy discernment of the } \\
\text { assertions in the text. All supporting } \\
\text { documentation contains appropriate } \\
\text { legends and footnotes such that they } \\
\text { "stand on their own". Readers are } \\
\text { referred to the tables and figures in } \\
\text { the text to support the factual } \\
\text { statements. Statistical findings are } \\
\text { appropriately delineated in the text or } \\
\text { tables/figures to highlight } \\
\text { significance. }\end{array}$ & $\begin{array}{l}\text { Results, statistics, and } \\
\text { supporting documentation } \\
\text { comprehensively presented } \\
\text { and explained to summarize } \\
\text { the findings of the } \\
\text { experiment, although the } \\
\text { writing is not connected } \\
\text { between paragraphs. Such } \\
\text { disconnection makes } \\
\text { comprehension or } \\
\text { understanding by the reader } \\
\text { challenging. }\end{array}$ & $\begin{array}{l}\text { The experimental results are } \\
\text { briefly reviewed in a succinct } \\
\text { manner, frequently listing the } \\
\text { data without connecting its } \\
\text { importance. Tables or figures, } \\
\text { while present, do not clearly } \\
\text { substantiate the findings. } \\
\text { Statistical analysis may be } \\
\text { general, descriptive statistics } \\
\text { without appropriate data } \\
\text { transformations or higher-level } \\
\text { analyses. Thus, a reader needs } \\
\text { to reread the results to } \\
\text { understand the authors. }\end{array}$ & $\begin{array}{l}\text { Writing of the results fails to } \\
\text { cover all of the research } \\
\text { findings, lacks statistical data } \\
\text { altogether to support the } \\
\text { facts, summarizes data but } \\
\text { fails to elaborate on specifics, } \\
\text { may lack supporting } \\
\text { documentation, and is not } \\
\text { written in a scientific manner. } \\
\text { A reader would be unable to } \\
\text { reach any conclusion about } \\
\text { the research even after } \\
\text { re-reading the results. The } \\
\text { information may be found } \\
\text { inconclusive, inadequate, } \\
\text { and/or spurious. }\end{array}$ \\
\hline
\end{tabular}




\begin{tabular}{|c|c|c|c|c|}
\hline $\begin{array}{l}\text { Discussion } \\
\text { (8 points) }\end{array}$ & $\begin{array}{l}\text { The results (data) are discussed in } \\
\text { relation to: the objectives and } \\
\text { hypothesis, why specific results were } \\
\text { achieved, statistical vs. biological } \\
\text { significance is explained and related } \\
\text { to the scientific (primary literature) } \\
\text { versus non-scientific (secondary } \\
\text { literature; trade journals, extension } \\
\text { publications for the public-at-large) } \\
\text { press, the previously published } \\
\text { primary literature } \\
\text { compared/contrasted with the current } \\
\text { study, how this research furthers the } \\
\text { scientific evidence, as well as } \\
\text { potential future experiments (or } \\
\text { replications of the same experiment) } \\
\text { that would be beneficial. }\end{array}$ & $\begin{array}{l}\text { Research findings are related } \\
\text { to the objectives and } \\
\text { hypothesis being tested, } \\
\text { why/how they were } \\
\text { achieved, comparative } \\
\text { analysis with the primary } \\
\text { literature, and the future } \\
\text { research needs. The authors } \\
\text { fail to convey one or more } \\
\text { examples of higher order } \\
\text { thinking. }\end{array}$ & $\begin{array}{l}\text { The results are reviewed in a } \\
\text { summative fashion and the } \\
\text { authors fail to convey multiple } \\
\text { examples of higher order } \\
\text { thinking, despite using } \\
\text { examples from the primary } \\
\text { literature. }\end{array}$ & $\begin{array}{l}\text { Discussion of the research } \\
\text { findings is not coherent, is } \\
\text { not integrated with the } \\
\text { primary literature, and fails to } \\
\text { demonstrate higher-level } \\
\text { thinking and cognitive skills. } \\
\text { It is unclear to the reader how } \\
\text { the current research furthers } \\
\text { scientific understanding. }\end{array}$ \\
\hline $\begin{array}{l}\text { Literature cited } \\
\text { ( } 2 \text { points) }\end{array}$ & $\begin{array}{l}\text { Includes primary literature citations in } \\
\text { the appropriate format for publishing } \\
\text { in horticultural journals (ASHS, } \\
\text { 2002). Secondary literature may also } \\
\text { be included but does not constitute a } \\
\text { majority of the citations. }\end{array}$ & $\begin{array}{l}\text { Primary literature citations } \\
\text { are included. Use of } \\
\text { secondary literature is } \\
\text { appropriate but } 1 \text { or more of } \\
\text { the citations are not } \\
\text { formatted correctly (ASHS, } \\
2002 \text { ). }\end{array}$ & $\begin{array}{l}\text { The number of primary and } \\
\text { secondary literature citations is } \\
\text { inadequate and/or many are } \\
\text { formatted incorrectly (ASHS, } \\
2002 \text { ). }\end{array}$ & $\begin{array}{l}\text { Primary and secondary } \\
\text { literature citations are } \\
\text { lacking, inappropriate, or the } \\
\text { majority of which are } \\
\text { formatted incorrectly (ASHS, } \\
2002) \text {. }\end{array}$ \\
\hline $\begin{array}{l}\text { Mechanics } \\
\text { ( } 2 \text { points) }\end{array}$ & $\begin{array}{l}\text { The entire lab report incorporates the } \\
\text { mechanistic tenets of professional } \\
\text { writing, including the use of SI units } \\
\text { (e.g. temperature, volumetric, length } \\
\text { measurements), proper grammar, } \\
\text { accurate spelling, taxonomic } \\
\text { nomenclature, scientific language, } \\
\text { proper sentence and paragraph } \\
\text { structure, verb tense, and avoidance } \\
\text { of personal pronouns as delineated in } \\
\text { the American Society for } \\
\text { Horticultural Science (ASHS) style } \\
\text { manual } \\
\text { (http://www.ashs.org/downloads/style } \\
\text { manual.pdf). }\end{array}$ & $\begin{array}{l}\text { Writing adheres to most of } \\
\text { the mechanics of } \\
\text { professional writing as } \\
\text { outlined in the ASHS style } \\
\text { manual } \\
\text { (http://www.ashs.org/downlo } \\
\text { ads/style_manual.pdf). The } \\
\text { authors fail to use at least } \\
\text { one of the mechanistic tenets } \\
\text { in their writing. }\end{array}$ & $\begin{array}{l}\text { The authors fail to convey in } \\
\text { their writing a majority of the } \\
\text { mechanics essential for } \\
\text { professional writing to convey } \\
\text { their findings to a national or } \\
\text { international audience } \\
\text { (http://www.ashs.org/download } \\
\text { s/style manual.pdf). This } \\
\text { occurs despite having the } \\
\text { components present in the lab } \\
\text { report. }\end{array}$ & $\begin{array}{l}\text { The writing throughout the } \\
\text { lab report fails to adhere to } \\
\text { professional mechanistic } \\
\text { standards of writing for the } \\
\text { horticulture discipline } \\
\text { (http://www.ashs.org/downlo } \\
\text { ads/style_manual.pdf), such } \\
\text { that the paper is incoherent to } \\
\text { both national and } \\
\text { international horticulture } \\
\text { audiences. }\end{array}$ \\
\hline
\end{tabular}

\section{Conclusion and Implications}

In this initial exploration of laboratory writing in horticultural science curriculum, we have found that there is a disconnect of what instructors expect in laboratory report writing versus what the learning outcomes are for their courses. This study delved into the courses taught in the Department of Horticultural Science exclusively. We concluded that the instructors link learning objectives with laboratory reports to reinforce course content. Students' ability to analyze results was seen as both a strength and a weakness. In lower division courses, analyzing results from student's experiments was a weakness, while in upper division courses the faculty responses were mixed as to whether students had the skills to sufficiently analyze results from their experiments. When a grading rubric was trialed, students indicated that use of the same rubric in other Environmental Horticulture courses would demystify the process of conducting research and communicating it effectively in laboratory reports. For this work to expand, rubrics need to be developed and used as well as encouraging dialogues with instructors in related departments to enhance our students' abilities to become competent in this form of written communication.

The conclusions from this study can serve as a framework to enhance student learning with the use of grading rubrics for laboratory writing. It is critical for the instructing faculty to link the course and laboratory learning objectives with the required writing, particularly laboratory reports. Since lower division undergraduate students had difficulty with analyzing results, additional instruction in the necessary statistics is essential to promote student learning. 
Future course development or enhancement would also benefit from the inclusion of rubrics to grade other writing assignments within horticultural science curricula.

\section{Acknowledgements}

Special thanks to Pamela Flash and the staff at the University of Minnesota, Interdisciplinary Studies of Writing for funding this research.

\section{References}

ASHS (American Society for Horticultural Science). (2002). ASHS Publications Style Manual. Alexandria, VA: ASHS Press.

Aaron, D.K. (1996). Writing across the curriculum: putting theory into practice in animal sciences courses. Journal of Animal Science, 74(11), 2810-2827. https://doi.org/10.2527/1996.74112810x

Anderson, N.O. (2000). Use of cooperative learning exercises to introduce concepts in potted plant production classes. HortScience, 35(3), 493.

Anderson, N.O. (2001a). Cultivar trial setup: A case study for potted plant production specialists. HortTechnology, 11(3), 481-484.

Anderson, N.O. (2001b). The Floratech Dilemma: A case study for potted plant production specialists. HortTechnology, 11(3), 477-480.

Anderson, N.O. (2002). New methodology to teach floral induction in floriculture potted plant production classes. HortTechnology, 12(1), 157-167.

Anderson, N.O. (2003). Integration of intensive writing into horticulture: Greenhouse Management. NACTA, 49 ${ }^{\text {th }}$ Annual Conference Abstracts, June 18-20, 2003, (p.38).

Anderson, N.O., \& J.D. Walker. (2003). Effectiveness of web-based versus live plant identification tests. HortTechnology, 13(1), 199-205.

Andrade, H.L., Y. Du., \& K. Mycek. (2010). Rubric-reference self-assessment and middle school students' writing. Assessment in Education, 17(2), 199-214. https://doi.org/10.1080/09695941003696172

Brillhart, L.V., \& M. B. Debs. (1981). Teaching writing-a scientist's responsibility. Journal of Research Science and Teaching, 10, 303-304.

Brookhart, S.M. (2013). How to create and use rubrics for formative assessment and grading. Alexandria, VA: Association for Supervision \& Curriculum Development.

Campbell, B., K. Loveness, A. Saalih, A. Buffler, \& F. Lubben. (2000). The communication of laboratory investigations by university entrants. Journal of Research Science and Teaching, 37, 839-853. https://doi.org/10.1002/1098-2736(200010)37:8\%3C839::AID-TEA5\%3E3.0.CO;2-W

Chandler, J.A., D.A. Fridley, M. Weber, \& M.K. Keith. (2005). Evaluating teaching effectiveness in a quantity food laboratory setting: phase one - Delphi panel study. Journal of Culinary Science and Technology, 4(1), 15-27. https://doi.org/10.1300/J385v04n01_03

Connors, P. (2008). Assessing written evidence of critical thinking using an analytic rubric. Journal of Nutrition Education and Behavior, 40, 193-194. https://doi.org/10.1016/j.jneb.2008.01.014

Davis, D. (1992a). Agricultural manager’s dilemma at St. Croix Valley Foods, Inc.: A decision case in processing crops agriculture. HortTechnology, 2(1), 100-109.

Davis, D. (1992b). Decision cases as a teaching component in the classroom and workplace. HortTechnology, 2, 96-99.

Dorman, D.C., K.M. Alpi, \& K.H. Chappell. (2013). Subject matter expert and public evaluations of a veterinary toxicology course brochure-writing assignment. Journal of Veterinary Medical Education, 40(1), 19-28. https://doi.org/10.3138/jvme.0912.082R

Foulk, D., \& E. Hoover. (1996). So what's wrong with the way I teach now?: Paradigms of learning. Minneapolis, MN: University of Minnesota Monograph Series, Center for Interdisciplinary Studies of Writing.

Foulk, D.S., \& E.E. Hoover. (1997). Sunny hollow orchard: A decision case as a basis for classroom discussion. 
HortTechnology, 7(2), 187-191.

Geisler, C. (2004). Analyzing streams of language: Twelve steps to the systematic coding of text, talk and other verbal data. Pearson/Longman.

Gibson, L.R., \& M. Liebman. (2003). A laboratory exercise for teaching plant interference and relative growth rate concepts. Weed Technology, $\quad$ 394-402. https://doi.org/10.1614/0890-037X(2003)017[0394:ALEFTP]2.0.CO;2

Haug, M. (1996). How to incorporate and evaluate writing skills in animal science and diary science courses. Journal of Animal Science, 74(11), 2835-2842. https://doi.org/10.2527/1996.74112835x

Holford, P., R. Ellis, \& A. Haigh. (2001). The writing portfolio as a tool for the development of communication and learning skills. HortTechnology, 11(4), 668-673.

Hoover, E.E. (1993). Using decision cases to improve horticulture education. Acta Horticulturae, 350, 39-44. https://doi.org/10.17660/ActaHortic.1993.350.6

Johnson, D.W., R.T. Johnson \& K.A. Smith. (1998). Active learning: Cooperation in the college classroom. Edina, MN: Interaction Book Co.

Lazarowitz, R., \& P. Tamir. (1994). Research on using laboratory instruction in science. In: D. L. Gabel (Editor), Handbook Research on Science Teaching and Learning (pp. 94-128). NY: MacMillan.

McLeod, S.H. (1992). Writing across the curriculum: An introduction. In: S.H. McLeod and M. Soven (Editors). Writing across the curriculum (pp. 1-11). Newbury Park, CA: Sage Pub.

Meyer, M.H., \& P. Allen. (1994). Dandelion dilemma: A decision case in turfgrass management. HortTechnology, 4(2), 190-193.

Moskal, B.M., \& J.A. Leydens. (2007). Scoring rubric development: validity and reliability. Practical Asessment, Research and Evaluation, 7, 1-11.

Moss, C.M., \& Brookhart, S.M. (2012). Learning targets: Helping students aim for understanding in today's lesson. Alexandria, VA: Association for Supervision \& Curriculum Development.

National Research Council. (1996). National Science Education Standards. Washington, DC: National Academy Press.

Ramey, S., L. VandeVusse \& M.B. Gosline. (2007). Using a written communication rubric to improve students' writing. International Journal of Learning, 13, 67-74.

Rudd, F., R. Greenbowe \& B. Hand. (2002). Recrafting the general chemistry lab report. Journal of Research, Science and Teaching, 31(4), 230-234.

Ryan, P., \& L. Walking-Woman. (2000). Linking writing to the process of scientific inquiry. Minneapolis, MN: Annual Meeting of the Conference on College Composition and Communication (p. 13).

The Center for Writing. (2004). Quicktips: Writing in the biological sciences. Minneapolis: University of Minnesota. http://writing.umn.edu/sws/quicktips/disciplines/biosci.htm

The Center For Interdisciplinary Studies Of Writing. (2000). Writing at the university: A survival guide for navigating the University's writing requirements. Minneapolis: University of Minnesota.

Whelan, R.J., \& R. N. Zare. (2003). Teaching effective communication in a writing-intensive analytical chemistry course. Journal of Chemistry in Education, 80, 904-906. https://doi.org/10.1021/ed080p904

William, R.D., S.L. Davis, L.A. Cramer, K. Stephens, R. Gresswell, G. Stephenson \& P.E. Corcoran. (1999). Team approach to teaching participatory group process involving natural resources and agriculture. Journal of Animal Science, 77, 163-168. https://doi.org/10.2527/1999.77suppl_2163x

Zambreno, K., E. Hoover, N. Anderson \& J.H. Gillman. (2004). Writing across the curriculum: where does horticultural science fit in? HortTechnology, 14, 621-624. 